\title{
Bodies in Motion: Rethinking Spaces and Borders Sociologically
}

\author{
Jonas Do Nascimento \\ University of Bayreuth, Bayreuth, Germany \\ Email: jonas.anasc@gmail.com
}

How to cite this paper: Nascimento, J. D. (2022). Bodies in Motion: Rethinking Spaces and Borders Sociologically. Open Journal of Social Sciences, 10, 424-441.

https://doi.org/10.4236/jss.2022.102030

Received: January 31, 2022

Accepted: February 25, 2022

Published: February 28, 2022

Copyright (c) 2022 by author(s) and Scientific Research Publishing Inc. This work is licensed under the Creative Commons Attribution International License (CC BY 4.0).

http://creativecommons.org/licenses/by/4.0/

\begin{abstract}
This article seeks to comprehend the concept of "space" and "borders" from several sociological perspectives, taking as an example the social experience of moving bodies in the context of globalization and international migration. Firstly, the different definitions of both concepts for the social sciences are discussed, and especially Georg Simmel's contribution to the study of social life as a "spatial dimension". Secondly, it considers the different variants related to the power relation and control of bodies, from a biological menace idea, in different spaces as the basis of social "inclusion" and "exclusion". Finally, it argues that the nation's spatial and border dimension is today being challenged primarily because of the migratory flows of different physical and especially virtual mobility forms. Based on these sociological concepts and notions, the article then tries to offer an expanded and complex perspective of "spatiality", "borders", and "displacement" in understanding the new political and cultural dimensions of contemporary societies.
\end{abstract}

\section{Keywords}

Human (Im)mobility, Borders, International Migration, Sociology of Space

\section{Introduction}

It is increasingly noticeable that the growth of the migratory flows has been causing a significant sociocultural reconfiguration in the north and south of the globe. On the one hand, while this diversification has become more visible, it has also generated conservative reactions and political discourses to defend an "authentic national identity" against the so-called "inauthentic newcomer groups". In this case, the divorce between "ethnonationalism" (Mortimer, 2011; Bieber, 2020) and "territory" (Sana \& Oloo, 2019) becomes a disturbing situation. Because in uttering such words, politicians such as Seehofer (Germany), Le Pen 
(France), Salvini (Italy), Órban (Hungary), for example, basically represent a "feeling", an "imaginary", or a "desire" that insists on wanting to create a "territory" that, on the other hand, resists in accepting a single form of to be "German", "French", "Italian", in short, "European". It means that in contemporary Europe, migration is a concern not only in controlling external factors (border control and national security) but especially in facing a new internal dynamic involving ethnic and racial relations (Thomas, 2013). In other words, the integration of these "new groups" into European societies implies the recognition of their cultural plurality.

Sociologically, we could say that "walking on space" is always a mode of "appropriation", that is, a transformation of space into a "meaningful space". Hence, the "mobility" of bodies is one of its prerequisites because it is our "everyday activities", by which we can imprint our traits and marks in and through space, forming our sense of "belonging", "citizenship", and "identity". Indeed, "physical space" and "mental space" have become an excellent framework for analysis both concerning dialogue and about contemporary cultural conflicts. As we will see below, if any of our cultural differences was supported by a division into very distant "experiential worlds", and the physical separation in different sets of situations fostered "distinct worldviews", these distinctions, for themselves, were also supported by the isolation of different people in different "plac$e s$ ", which led to different social identities based on specific and limited experiences. However, by bringing many "different types of people" into the same "space", electronic and visual media (read: internet, telephone, television, cine$\mathrm{ma}$ ) have fostered a weakening of many previously distinct social roles. In this way, the "virtual world" (Ponzanesi \& Leurs, 2014) affects us today not primarily through its "content", but more especially by changing the "situational geography" of social life.

Thus, "migratory practice", or rather, "human mobility", can be correctly considered a displacement of people in space, but this "space of displacement" is not just a "physical space". It is also a space-qualified in different senses: socially, economically, politically, culturally, imaginatively, and digitally, through which people add new repertoires to their "living spaces" (Baleisan, 2014). Traditionally, this phenomenon was also called "space-time compression" (Harvey, 1992). However, it needs to be socially differentiated, and this is not just a moral or political point about the inequality of relating to these different spatial "interconnections", but also a conceptual point. According to Doreen Massey (2005), the usual interpretation that the "spatial-temporal compression" and the geographic stretching of social relations result overwhelmingly from the "actions of capital" and its increasing internationalization leads us to think that they are just the "time" and "money" that make the world go round. But, apart from capital, mobility (or the absence of it) today more than anything reflects a "geometry of power".

Although the new "post-colonial" geographies may have the ability to "question" and "destabilize" much of the dominant discourses of Western na- 
tion-states, efforts must be redoubled to integrate into these reports also the known patterns of prejudice, inequality and violence that characterize the experience of contemporary international migrants and their communities - that is, "the doors" and "the bridges" they come across on their way. For, despite the increasing porosity of national borders and the "heterogeneous spaces" of most States, the "flows" of people continue to be "monitored" and "controlled" by government institutions as never before in history. It means that the practice of national States continues to operate powerfully under the logic of a world of "spatialized essences" (Agnew, 2009). In the sense of "prophylaxis", as if the (social) body had to assure itself of its own identity by expelling "debris" (Gilroy, 2007). Based on these sociological concepts and notions, this article then tries to offer an expanded and complex perspective of "spatiality", "borders", and "displacement" in understanding the new political and cultural dimensions of contemporary societies.

\section{Social Dimensions of Space}

For a long time, we got used to thinking of "space" as a mere receptacle, an empty and inert container occupied by bodies and objects after a long period of years (Lorea, 2013). Only then would it become completely intelligible, transparent, objective, neutral and, at the same time, immutable and definitive. However, unlike this perception, the notion of space carries different meanings, depending on our "usages" in different disciplines and contexts. By systematizing the conceptions of space throughout recent history, Benno Werlen (1993), in his book "Society, Action and Space", for example, establishes three different positions for the notion of space for reflection: the substantive, the relational, and the epistemological notion. The substantive (or absolute) notion of space can be related to the ideas of Descartes and Newton, for whom space and time would have an "absolute", "substantial", and "distinguishable" dimension. Thus, space for Newton would have a stable, continuous, and immobile existence, in its nature, and unrelated to anything external to it.

For Descartes, in turn, space would also have an absolute condition, but one that dominated the senses and the body in such a way that it became a repository of the immanent order of all existing beings. The idea of space, for both perspectives, would therefore be something fixed, substantial, and measurable. However, from a relational point of view, space itself could not be considered an absolute and substantial entity, as postulated by Newton and Descartes. According to Leibniz, space cannot just be what it is "with nothing". Much less could space be a mere compilation of all the things in the world. Thus, the "space" becomes, in his perspective, something merely relative to, because it would represent an "order of coexistence" as time would represent an "order of successions". Space, in this sense, would not pre-exist in the vacuum. On the contrary, we must first occupy it with our bodies that indicate a direction, a gesture, since, without bodies and objects, "space", in itself, is nothing. It is for this reason that "space" 
would be relational. The epistemological notion of space, represented mainly by Kant, takes up the Aristotelian notion of "category" (intermediate elements between concepts and knowable reality) to think about "space", and also "time", as an a priori of the human mind and a mental category that makes knowledge possible. In this way, all things we perceive in the world come to have Spatio-temporal dimensions that we assign to them based on our own "mental structure". Therefore, the existence of space would be unique since it would not exist in reality as we represent it. Still, its existence would only reside in our minds as a "category of knowledge" that we must organize and classify reality.

Facing these three perspectives of thinking about space throughout the history of modern thought, Werlen (1993: p. 3) will state that "space is neither an object nor an a priori, but a frame of reference for actions". For him, "space" would be a referential background for the material aspects of social actions, in the sense of a formal classificatory concept, and not an empirical idea. Therefore, we must investigate the "space" as a condition and result of social actions. Fundamentally, the space becomes the support and a "field of action". In a similar viewpoint, John Urry (2004) will state that "space" is constituted and formed by a set of interactions "between entities" that form a society. Therefore, in this logic, it would not be possible to have "social relations" without space, just as there would be no "space" without social relations.

Any concept of "space" can only provide a frame of reference through which material entities, based on their actions, can be reconstituted, and located. However, this qualification of space as a framework in which we inscribe our social actions can also be misleading, as the word "space" always suggests something physical and tangible, although here, the idea of "space" is closer to Leibniz's approaches, "space" as a social relationship. Consequently, "space" is not a neutral medium that stands apart from how we perceive and conceive of it. Of course, we can trace and dispute various changes in "space configuration", alongside different forms of knowledge and social relations. Far from being naturally "given", "space" carries a history, that is intertwined with thoughts, creating different objects for "knowledge" (Burgin, 1996). Therefore, what some authors call "spatial turn" (Löw, 2013: p. 17) is the perception that we cannot satisfactorily explain the social world without reconceptualizing categories related to the spatial component of life in society.

In other words, the spatial turn standpoint defends that "space" is not just something "natural", a container, or receptacle of objects and people, or a mere setting, but a condition and result of "social processes". In that way, "space" is conceived as a relational attribute, expressing the positions and perspectives of social relations. From this angle, we can perceive and analyze how "spatial differentiation" is linked, in fact, to different forms of "social relationship". Here, there is an understanding that between "space" and "society", there is not only an indestructible link but a relationship of a recursive order, of mutual influences. In this sense, "spatiality" becomes a powerful tool in revealing society's 
aesthetic, political, social, and historical meanings. Therefore, the emergence of new "spatialities" in contemporary societies would go hand in hand with reconfiguring "subjectivities".

In the sociological tradition, "spatial considerations" were mainly linked to reflection on urbanization and its consequences in culture or behaviour. With the advent of modernity and its impacts on traditional social structures, practices and relationships, and the construction of new subjectivities, spatial dynamics play an essential role in studying the daily interactions of the new "modern metropolis". However, most of the classic writings on the social transformations imposed by modernity, and the emergence of capitalism, did not directly address space as an object of theoretical discussion. Earlier, they detected and analyzed the contradictions, conflicts, contrasts, and paradoxes existing in the tradition-modernity relationship in a relevant way.

For example, Durkheim (1999) in "The Division of Labour in Society" will create the concepts of "mechanical solidarity" and "organic solidarity" to refer not only to two forms of social organization but, more specifically, to the transition from a "traditional society" to a "modern society". Similarly, Tönnies (1979), when reflecting on the differences between "community" (Gemeinschaft) and "society" (Gesellschaft), provides us with the possibility of thinking about these social formations as embodied in different "spatial modes".

Thus, among the "classics" of sociological thought, Georg Simmel was the only one to propose a "sociology of space" directly ("Soziologie des Raums"). Strongly influenced by the tradition of German Lebensphilosophie, or "philosophy of life", Simmel sought to analyze the lived experience of individuals. With this, the German sociologist thought of social phenomena as "forms" that we can only study through the analysis of their manifestation in the bodies that interact with them; that is, in the "real individual processes" that constitute social structures (Frisby, 1992). Thus, Simmel argued that individuals have values and pursue goals that derive from the contents of "social forms". However, the actors in their social "interactions", and "space" would play a fundamental role in this process -, reformulate these "contents" and "forms" of socialization. Thus, we would perceive the things that surround us according to their "spatial dimensions", and these dimensions have a strong social meaning.

Simmel also insists that social formations are in constant flux and dynamism through the reciprocal interaction between "social form" and its "cultural content". In this sense, there would be no "fixed things" or "events" with intrinsic meanings, and they would only emerge through interaction with other events or things. Starting from this relational assumption of social life, Simmel creates the basis for imagining the multiple ways in which society is "spatial. He does, however, warn against the error of objectifying "space", generally seen as a force independent of history: "Space always remains the form in itself without effects, in whose modifications the natural energies do indeed reveal themselves, but only in a way analogous to how language expresses thought processes that take 
place in, but not through, words" (2013, p. 75). In this way, "proximity" or "distance", "clustering" or "dispersion", "density" or "dissemination", "permanence" or "mobility", would all be spatial attributes: "It is in the requirement of specifically mood functions for each of the historical figurations of space that the fact that space, in general, is only an activity of the soul, only the human way of uniting sensory stimuli that are disconnected in themselves into unitary visions, is mirrored" (2013, p. 76).

When discussing "personality contents" that shape space, Simmel highlights human relationships and spatial importance to a certain "social order". Unlike Werlen's perspective, here, "space" is not seen only as of the "field of action", but the "condition" and the "symbol" of the relationship. Therefore, according to Simmel, the "human experience" would be necessarily a "spatial experience" insofar as "space" is as vital for the manifestation of social forms as language is for thought. He then constructs a "sociology of space" based on five fundamental spatial qualities: 1) "uniqueness"; 2) "border (or boundary)"; 3) "fixation"; 4) "proximity and distance"; and 5) "mobility".

Regarding "exclusivity", Simmel argues that two bodies cannot simultaneously occupy the same space, and it means that "space" has a kind of "singularity" for which there would be almost no analogy. Because each group occupies a "spatial part" and can never coincide, although their composition is unitary, it occurs with the "territory", which constitutes the condition for the three-dimensionality of space to be fulfilled and fruitful. Thus, in a specific "spatial zone" that fulfils one of the configurations of a given type of "association", there could be no place for a second spatial configuration: "Within the limits of a city, there can only be that city; and if by chance, a second one emerges within these same limits, then they are not two cities on the same ground and the same land, but in two territories once in fact united, but now separated" (Simmel, 2013: p. 77). However, according to Simmel, two or more configurations of different types can cohabit the same "spatial perimeter" without there being a "spatial collision" (metaphorical sense) because, as "sociological formations", they would not be defined spatially, but in terms of place (geometrical sense). Here, it is clear that the notion of "space" and "territoriality" carries in Simmel a meaning beyond the meaning traditionally consecrated to these words. "Space" and "territoriality" thus become not so much "geographic" notions, but exceptionally "imagined notions". For its "functional" use, "space" is divided, delimited, framed by "limits" and "borders" that both express and sustain the unity of a group. Such "frames" would announce that within them is a "world" subject only to its own "norms". The "content" of this effect is precisely the determination of not wanting or not being able to operate beyond these "limits". However, if this general notion of "border" derives from the "spatial limit", this limit is only the "crystallization", or "spatialization", of animic or sociological limiting processes. Since, as Simmel (2013: p. 81) argues, "the limit [border] is not a spatial fact with sociological effects, but a sociological fact that takes its shape spatially". This statement allows 
us to understand how "spatial phenomena" are, on the one hand, social constructions and how, on the other hand, social configurations are "spatialized".

\section{Space, Power and Colonialism}

\subsection{Typologies}

Since "space" carries social meanings, and these are always plural, it is constantly being "shaped" in contexts of continuities, connections, and conflicts. The home, the public, the city, in their interconnections with the "different spaces", form layers of the "belonging spheres", and they, together, form the puzzle of the context where social relations, communication and action occur and shape the meanings of identity and community. In this sense, knowing "where we are" becomes an essential element in the attempt to know "who" we are (Silverstone, 2004; Nascimento, 2022).

As Doreen Massey (2005) emphasizes in "For Space", space becomes today, above all, a "problematic space". Her discussion of space is based on three fundamental propositions: 1) space is a product of interrelationships, that is, constituted through interactions; that 2) it is a sphere in which distinct trajectories coexist [...] therefore of coexisting heterogeneity; and that 3) is always under construction. Both conceptualizations of space help us to understand how contemporary societies are characterized by the possibility of individuals to move (in the geometric and metaphorical sense) from one place to another as never before and point out an element that has excellent analytical relevance: "spatial proximity" does not necessarily mean "social proximity".

It is no coincidence that many contemporary authors' schemes for analyzing globalization (such as Appadurai and Canclini works, to name two) resemble Simmelian premises. Some of these authors argue that the essence of globalization lies in the intersection between mass media culture and mass migration, in which we see moving images aimed at spectators who are themselves "extra-territorialized". Indeed, with what has been explained above, one can understand more clearly how the structures of "metaphorical" and "geometric" interactions unfolded in "space" and "time" to create an "objective culture" as channels of the great currents of material and symbolic exchange of today. What changes in the current situation is precisely the impact of these "spatial attributes" on social relations: the condition of proximity, changes in mobility, displacements and variations between density and distance, the suppression of limits, or borders between territories, all these elements change with the dynamics of a globalized society, directly affecting social relations. For example, racial, class, and ethnic segregation and hierarchy systems are among the most prominent features of globalization, not just in rich countries but everywhere (Ethington, 2005).

Therefore, the aspects analyzed by Simmel and other theorists can teach us to place the fundamentally spatial condition of "being" in the historical movement by identifying and analytically deconstructing how social and spatial construc- 
tions generate "social subjects". We can then understand "space" as the "practice of place", that is, the way subjects transform it from their occupations, appropriations and experiences. In daily life, the individuals symbolize a "place" from their interferences, both "corporeal" and "cognitive". Starting from this premise, Michel de Certeau (1998: p. 202, emphasis added), in his studies of everyday life, for example, will state that "the street geometrically defined by urbanism is transformed into space by pedestrians". With this, Certeau sought to emphasize that it is our "steps" that "shape" places and transform them into "spaces". By being appropriated, the "place" is thus transformed into a "space" full of social meanings for specific individuals and groups. Marc Augé (2000), in his now-classic study of contemporary "non-places", will argue that "places" are composed of a triad of elements: 1) identification, 2) relationship and 3) history. What we call "place" is, then, a "material" and "symbolic support" in which different temporalities are intertwined, present, past and future. In this way, every "place" would be like a "collective work", loaded with meanings from which "sociospatial" practices, including the routines of everyday life, serve as mechanisms that reaffirm a "semiotic world". The "place" would thus be concrete and symbolic construction of "space": "at the same time a principle of meaning for those who inhabit it and a principle of intelligibility for those who observe it" (Augé, 2000: p. 30).

\subsection{Spatial Hierarchies}

Since "place" is a kind of symbolization of "social space", no place is not hierarchical in a hierarchical society, and it does not express distorted and naturalized social distances. It is in this way that specific differences that are fundamentally historical appear as "natural", such as the idea of a "national frontier" or the "spatial projections" of social difference between the sexes in church, school, and public places. Therefore, talking about "space" and "power" leads to thinking about two essential and interrelated dimensions: the "physical plane" and the "social plane". Between these two dimensions, there is an intimate connection in which the "material dimension" appears as a "crystallization" of what happens in the "social dimension", symbolic plane. Just as individuals and things occupy a "place" in the physical world, in the "social space", individuals also do so, so that they occupy a "certain position", with a "distance" between them, forming an accurate "social topography".

In this sense, a change in "social position" results in "spatial location" changes. Thus, the "inhabited space" (or appropriated) would function as a kind of spontaneous "symbolization" of the "social space". However, the "translation" of "social space" into "physical space", unlike what one might imagine, has a nebulous character. This opacity is underlined by Pierre Bourdieu (1990) when he refers to how space "naturalizes" the various modes of domination and power. That is why when referring to "space" in a "material" sense, Bourdieu prefers to call it "objectified social space". It brings us especially to "fixation", one of the 
defining elements of the space proposed by Simmel. For the German author, the character of "fixation" requires that the spatial component be produced, reproduced, and legitimized. As support and anchor for social relationships and memory, "spatial fixation" works as a "rotation point", to which individuals have subjected: "large organizations need, as such, a space centre; is that they cannot do without a superior and inferior order, and whoever gives the orders must, as a rule, have a fixed place of residence in order, on the one hand, to have their subordinates at hand, and so that, on the other hand, they know where to find the boss at any time" (Simmel, 2013: p. 89). It means that "power", no matter what kind, uses "space", on the one hand, as a way of embodying itself or becoming tangible, and, on the other hand, to grant a "duration aura" to something that is, in reality, a socio-historical construction.

It needs not only stability but also components that evoke in people the idea of permanence, and space is an element that, based on its "fixity" and "anchoring", makes this "image" possible. Indeed, political, and social domination almost always becomes a "semantic-spatial" device. Political and religious institutions, for example, build monuments of various types, such as altars, palaces, temples, tombs, statues, in order to frame, singularize and give historical, sociopolitical, and spiritual transcendence to figures, characters and events, thus seeking to break its "temporal contingency". In this way, "space" would not only become a matter of "ethics" but, more significantly, a matter of "aesthetics" (Nascimento, 2021).

Still, according to Bourdieu, there would be a close connection between "social space", "physical space", and "mental space" here. For him, the social world is objectified, introjected, and incorporated by social actors in many ways so that "social space" manifests itself not only in "physical space" but also in the "mental devices" that individuals construct to understand the social reality. Above all, this proposition allows us to think about the close relationship between "cognitive" and "geometric borders". Both dimensions highlight a fundamental quality of space as an "analytical structure" in the study of "cultural practice": the feeling of belonging or not to a "space" and its spatialization in the form of subordination, exclusion, and participation. In this way, in a Bourdieusian sense, owning "capital" presupposes power over "space" and "time". However, Bourdieu notes that it is not enough to have "economic capital" for a social actor to inhabit it. A "collection of knowledge" is also necessary, allowing mobilizing, unfolding, and dominating a specific space. In other words, "inhabiting" and "owning" a space also requires social actors to know the rules and codes of the "place in question", and this requires a specific "cultural capital". Otherwise, the individual risks being evicted or not being accepted.

The relevance of possessed capital, therefore, not only resides in the "power over space" that individuals or social groups can maintain but also in the fact that it functions as a "mechanism" of distinction and "social" and "spatial" distance with "undesirable" social groups. In any case, according to Philip J. Ethington (2005), Bourdieu would still need to be "re-spatialized" in the Simme- 
lian sense, since when the French sociologist deals with "geometric space" and "metaphorical space", he does so separately. On the one hand, the habitus would present itself as a structured body of "social practices"; and, on the other hand, its "social topology" would represent a "metaphorized space" of social positions. These relative positions in the space would then define agents and groups of agents, and each of them is confined to a specific position or class of neighbouring positions. However, what happens if we place Bourdieu's "social topography" in a historical circumstance?

Taking as an example the experience of colonialism, the so-called "blood cleansing" laws, which emerged as a religious-colonizing discourse, were transformed into tools of "racial schematization", whose principles of generation, degeneration and regeneration of colonial reproduction patterns would lead to the gradual emergence of a system of "social classification". In Bourdieu's sense, this situation can be seen as a clear example of the historical development of a "social topography". Nevertheless, as is also known, these "racial ideologies" were also inserted in the "geometric dimension", based on "formal segregation" in colonial cities together with the development of a "racial conscience".

\subsection{The Space of Coloniality}

The "spatialization" of social domination in the colonial context was also an aspect addressed by Frantz Fanon. The Martinican psychiatrist described the colonial administration and the anti-colonial struggles in spatial terms. Specifically, concerning national liberation struggles, Fanon (1968) describes such a movement mainly as a "claim to the city" and as a practice of "reappropriation" and transformation of "colonial space". Indeed, true liberation represented counter-hegemonic strategies for democratic self-determination, which rested on an eminently "socio-spatial" alliance that did not reproduce "colonial spatial arrangements". Fanon anticipated the neocolonial urban modernism that meant the "socio-spatial" isolation of the African national bourgeoisie. Specifically, in this context, the colonial production of homogenisation/separation of the colonized groups was spatial (demarcation) and temporal (linear and repetitive). It meant that colonial "time" and "space" profoundly impacted the colonised's imaginary worlds and body experiences. For example, the racialisation of the everyday space of cities in the colonies made it difficult to "relieve anonymity" provided by the modern city, as the colonized people were reduced to their "physical appearance", and this was only possible by placing the "black bodies" in a "black body place". As Nigel Gibson (2003: p. 133) asserts, this form of "objectification" made it impossible to escape from "body confinement" and at the same time denied the possibility of freedom, that is, a reciprocal spatial relationship between the "body" and the "world". Thus, a "revolutionary action" in such a context necessarily implied the transformation of "urban space" in all its dimensions since it was in this space that "everyday life" and "social formations" were articulated. 
Therefore, only a national liberation organization that encompassed the colonially administered division of "space" could overcome the "social ontology of the colonial city" (Turner, 1996: p. 135). In fact, according to Fanon, decolonization should be considered in a double sense: 1) of political liberation and 2) of micrological transformations of everyday life. To the extent that, as Stefan Kipfer (2007: p. 718) sustains “in Fanon's work, colonial space was a conceived product of colonial planners oriented to dominate, homogenize, and exclude. At the same time, colonial abstract space integrated the colonized into colonial abstract space through daily spatial practices and affective, bodily spatial experiences. These practices and experiences were paradoxically shaped by a dual, profoundly gendered process of homogenization and serialization (of racialized colonial subjects) and separation and confinement (of those same subjects, who are segregated in non-European space and domestic life). In turn, colonial abstract space is full of peculiar contradictions such as the corrosion of the patriarchal family and peasantry under the pressure of rural urban migration and strategies of 'unveiling' domestic space". Thus, temporarily reappropriating the streets, according to Fanon, meant not only confronting the "formal (European) city" and the spatial restrictions of the "informal (native) city", but also overcoming the considerable number of "taboos" by the forms of peculiarly racialized confinement of colonial space. The freedom, for example, acquired by walking not "along the walls" but "in the middle of the sidewalk" presupposed a transformation of the relationship between the "body" and the entire "social order" (Sekyi-Otu, 1996). With this, Fanon suggests that the manifest measure of "colonial exploitation", the palpable index of its "totalitarian character", should be found not primarily in the rate of "surplus value" of economic exploitation but in the magnitude of the "physical" and "metaphysical" abyss that divided the colonizer and the colonized.

\section{Reconsidering the "Others" in the National State}

Given the recent controversies over the use of the veil in different European States, and especially in France, which is strongly intertwined with a specifically urban history of the handling of Parisian "suburbs" (the so-called banlieue) as places of "deregulation" and "disrespect" to the immigrant population, Fanon's urban reflections become significant in the contemporary context. Today, the coloniality of everyday life means considering the various ways in which the practice of colonialism has outlived its history. With the decline of official colonial rule in the 1960s, ex-colonial metropolises seem today to forge a form of "internal colonialism" (Turner, 2018), where rational administrative techniques developed in ex-colonies during the colonial period are used alongside new technologies to control "undesired bodies", that is, "immigrants", "strangers", "false nationals", as the extreme right politicians like to classify them.

On March 15, 2019, an attack on three mosques in New Zealand left open, once again, one of our significant contemporary problems: the "danger" that 
migration has symbolized for the "purity" discourses of ethnic nationalism. The massacre committed by a 28 -year-old New Zealander, which left at least 49 people dead and 20 more injured, says a lot about our time in two ways: 1) an exacerbated fear of the "other" as an element considered "polluting" of a supposed "homogeneous space" of the nation; and 2) the increasingly tenuous barrier between what we consider "real" and "virtual", given that the entire massacre was carried out and broadcast live on Facebook. On his Twitter account, the assassin proclaimed himself "an ordinary white man from a normal family" who, he continues, decided "to defend a position to secure the future of his people". In addition, his text also described immigrants as "a group of invaders" who "want to occupy the lands of my people and ethnically replace us" (BBC News, March 15, 2019). The "content", as we know, is old, but nowadays, it has been materialized in new "forms".

By developing theories that perceive space as a relational process, we are faced with the problem of theorizing and empirical understanding of "borders" in terms of "socio-spatiality" (Fuller \& Löw, 2017). Even though what we understand by "space" is considered dynamic, that is, produced and generated through our individual and collective "meaningful practices", the "borders", based on an idea of "purity", exist and are defended and raised in many contemporary nation-states, reaching extreme cases like the example mentioned above. In fact, in 1990, according to Reece Jones (2016), twenty countries had walls or fences on their borders, and by early 2016, that number had risen to nearly seventy. As its spokespeople call it, the effect of this type of "protection policy" is none other than to produce or exacerbate the very problems it is intended to solve. That is, forcing the migrant population to take more dangerous routes (across the Mediterranean to Europe in unsuitable boats, in cramped containers, wedged inside the engine compartments, or stuffed into the trunks of cars), with an increasing reliance on traffickers of people, which in turn encourages states to repress them further.

As we have seen, Simmel believed that the "border" was a "sociological fact" that took its shape spatially, not the other way around. Thus, the "border" would fulfil a fundamental function: to make life meaningful and locatable - providing "direction" and "order" to those who inhabit its limits. At the same time, the "border" "localizes us", providing us with the feeling of "belonging to" somewhere. However, it also implies an "out of place", thereby establishing differences between "us" and "them", between "here" and "there". The consequences of this type of differentiation based on "dividing lines", as true "hygienic lines", can be multiple: from structuring the concession and denial of access to a specific "space" to the strengthening of political and economic processes of exclusion (Sassen, 2014).

In these terms, the border emerges historically not only as a common practice of "governing space", but above all, and with greater relevance, as "a device for inclusion and exclusion of people, as well as a technology that shapes ways of states of being and mentality" (Leppänen, 2017: p. 137). It means that "space", as 
we have explained so far, carries a "real" and "imaginary" meaning. That is, "it links the mental and the cultural, the social and the historical" (Lefebvre, 2003 [1986]: p. 209). Furthermore, concerning the formation of the modern nation-state, the "space-territory" model, on which it is based, almost always tends to "homogenize" (through physical or symbolic violence) everything that is within this "territory". In this sense, "modern nationalism" is born fueled by the idea that, the "perfect world" would be one that would forever remain identical with itself, a world in which the wisdom learned today would remain wise tomorrow and the day after, and in which the skills acquired through life would retain their usefulness forever a transparent world, in which nothing obscure or impenetrable stood in the way of the gaze; a world where nothing would spoil the harmony; nothing "out of place"; a world without "dirt"; a world without strangers (Bauman, 1998: p. 21).

Consequently, the "Nation-state" emerged and remains as "an imagined political community, and imagined as being intrinsically limited and, at the same time, sovereign" (Anderson, 2008: p. 32). By speaking of "imagination", Benedict Anderson wanted to highlight that the "national conscience" is shared and experienced as a "community of feeling". In other words, a Nation establishes "imaginary bonds" that assemble memories of events and "common political destinies" for the "people" that inhabit the same "territory", with its "founding fathers, its basic, quasi-religious texts, a rhetoric of belonging, historical and geographical landmarks, enemies and official heroes" (Said, 2003: p. 48).

In fact, regarding the "origin of nationalism", Anderson concludes that what we call "nation" exists only because of an idea and imaginary of "simultaneity". That is, the "feeling" shared by many, of belonging "to the same space". In this way, the modern conception of the "Nation-State" is born dependent on ideologies and practices of well-defined borders, represented in an ideal of "compact" and "isomorphic" organization of the territory, and, more significantly, of a "territory of purity". However, as the world becomes globalized in terms of economy, trade and investment, borders are more easily opened for a free flow of goods, products, and human contingents. In the same way, culture and communication have become increasingly deterritorialized and transnational (Balibar, 2004; Robins, 2007). Thus, the "differences" pile up on top and become objects of negotiation (Zambon, 2016).

Furthermore, the current socio-cultural condition inevitably creates "a rupture between the politics of the nation and the human condition within nations" (Georgiou, 2010: p. 25), because if every "purity scheme" generates its own "dirt" (the "others"), that is, "strangers" that become immune to their "fixation" (as "polluting agents"). As stated by Abdelmalek Sayad (1998: p. 274): "the immigrant puts the national order at 'risk' by forcing to think what is unthinkable, to think what must not be thought or what must not be thought in order to exist". Today, the "freedom of flows" of goods, people and images does not become, by definition, liberating, but, more significantly, becomes an element of transgres- 
sion, since it clashes with the restrictive powers of the "physical" and the "national", that is, with the "purity" and the "order" of a world that claims to be "stable" and "predictable".

As Ulrich Beck argues, the consequence of migration over time has represented the transformation of "the experiential spaces of the nation-state from within" (Beck, 2006: p. 101). However, in the face of the "danger" of "contamination", "purity" rises more and more each day. According to Mary Douglas (1991: p. 31), "our behaviour in the face of pollution consists of condemning any object or any idea that may cause confusion or contradict our precious classifications". In this sense, raising borders appears, therefore, as a "form of defence" against those "agents" that, deep down, may threaten our "ontological security".

Thus, the contemporary nation-state crisis reflected the increasing distance between the "territorial sovereignty" linked to the State and what we currently call "nation". According to Paul Gilroy (2001), for example, the diasporic and immigrant community would break a sequence of explanatory ties between "place", "position", and "consciousness", opposing the power of "territory" in wanting to determine "identities". For him, by occupying the "place of the border", or a "space of questioning", the diasporic and immigrant subject would be able to articulate new cultural values, providing the emergence of what was previously to the detriment of a concept totalizing or hegemonic, in the case treated here as the values of a "territory of purity" and its "homogenizing spaces". Hence, Gilroy refers to the feeling of "deterritorialization of culture" as opposed to the idea of a "territorially closed culture" and "encoded in the body": "Under the diaspora key, we can then see not a race, but geopolitical and geocultural forms of life that result from the interaction between communicative systems and contexts that they not only embody, but also modify and transcend" (Gilroy, 2001: p. 25).

Moreover, the English sociologist repudiated the idea of an identity rooted in a supposedly "authentic", "natural", and "stable space", as conveyed by nationalist thought. For Gilroy, the transnational communication network has created a "new topography" of loyalty and identity that disregards the structures and assumptions of the nation-state, thereby redefining the forms of connection and identification in time and space. For this reason, for example, the analysis of black political and cultural history in the West would require greater attention to the complex mixture between European and African philosophical and cultural ideas and systems. However, we should not here interpret the "mixture" as a "loss of purity" but as a growth principle that helped form the modern world. Gilroy presupposes the idea that "racial terror is not merely compatible with Western rationality, but voluntarily complicit in it" (Gilroy, 2001: p. 127). If it has a "desire for fixity" and "otherness" limitation, as a way of "protecting identities", that attitude denies the fact that the "other" already exists "inside".

Thus, the problem is not simply the "individuality" of the nation as opposed to "other" nations. We are now facing a nation divided within itself, articulating 
the heterogeneity of its population. Alienated from their eternal "self-generation", contemporary Nation-Stations have become "a liminal space of meaning, which is internally marked by the discourses of minorities, by the heterogeneous histories of disputed peoples, by antagonistic authorities and by tense places of cultural difference" (Bhabha, 1998: pp. 209-210). From the margins of modernity, at the impossible of telling their stories, we find the question of "cultural difference" as the perplexity of living and, at the same time, writing the "nation", these groups resisting being placed within of a unison discourse, becoming themselves "moving borders", which constantly alienates the borders of the modern nation.

\section{Conclusion}

As we could see above, today we are facing new forms of "connections" in the contemporary world that extrapolate the logic of "co-presence" and "territory". According to Urry and Grieco (2011: pp. 4-5), currently, social relations would not be fixed or located only in one place but would be constituted by several "circulating entities": objects, people and images that carry connections between various "spaces". These "connections" often involve pervasive movements in space, and there would be different mobilities that form and reform social life: the bodily journey of people for work, leisure, or escape. Besides, the physical movement of objects (food, merchandise, gifts ...); imaginative journeys through films (building and reconstructing visions of places); virtual travel in real-time via the internet, transcending geographic and social distances; communicative journeys through messages, letters, emails, telephone calls, among others.

Indeed, thinking about "mobility" today suggests that movement is not only experienced by "migrants", but that is part of the human condition in the contemporary society. It means that, ultimately, there would be many ways to reassert "community" through movement, and this would not necessarily reside in "real movement" or "physical proximity", because "places are also always interconnected, in addition to borders, in many other places, through journeys and imagined journeys" (Urry, 2004: p. 29, our translation). Thus, we can think, for example, of the formation of new communities anchored in a "sense of place" that is "extroverted", including connections with the broader world, or integrating both the global and the local in a "communicative circuit", not as opposing points, nor as cause and effect, but as coexisting elements.

Based on this, many authors will emphasize connections between the issue of migration (or mobility) in the "real world" and the possibility of travelling in the "imaginary" through the different means we have at our disposal. This aspect is considered by Sandra Ponzanesi and Koen Leurs (2014: p. 3) when they create the term "digital crossings". They use the term to explain how the use of digital technologies today "enables the maintenance of new forms of diaspora" and networks, operating inside and outside Europe, making issues of ethnicity, nationality, race and class not obsolete but transformed". In their sense, technology 
is coupled to a continuous "material reality" of everyday life, ordinary and extraordinary, connecting both worlds, "offline" and "online", both interconnected in everyday practices. This creates a kind of continuum between digitized life experiences and materialization, integrating these technologies into "social reality" and guiding our perception of places, tight spaces, and unfamiliar spaces.

Thus, it can be said that the socioeconomic and cultural causes of migration today are, in most cases, "collective". "We are here", say the immigrants, "because you were there!". "We do not cross the border; the border crossed us", as Seyla Benhabib (2012) provokes in her text "The Morality of Migration". Thus, it is up to us to ask how these "spaces" and "borders" today represent different degrees of violence, translated in movement or in fixity as a conflict between the "desire for freedom" and the "desire for control", between certain people who move and other people who want them to stay in place. Consequently, the immigrant's body becomes, at this moment, the very "symbolic site" on which all these contradictions are enacted. As anthropologist Low (2009, p. 22) highlights, "it is through embodied space that the global is integrated into the inscribed spaces of everyday life where affection, emotion and morality come into play". Therefore, from a sociological perspective, "space" and "morality" are terms that guide us towards something fundamental and new in contemporary cultural processes: 1) an organized field of "social practices" and 2) a privileged "place of negotiation" of identities and collective histories.

\section{Conflicts of Interest}

The author declares no conflicts of interest regarding the publication of this paper.

\section{References}

Agnew, J. (2009). Globalization and Sovereignty. Rowman and Littlefield.

Anderson, B. (2008). Comunidades Imaginadas: Reflexões sobre a origem e a difusão do nacionalismo. Tradução de Denise Bottman. Companhia das Letras.

Augé, M. (2000). Los “no lugares”. Espacios del anonimato. Editorial Gedisa. Bauman, Z. O mal-estar da pós-modernidade. Jorge Zahar, 1998.

Baleisan, C. P. (2014). Estudiar un postgrado en el extranjero: ¿una migración previsible? Revista Sociedad y Equidad, No. 6.

Baleisan, C. P. (2014). Se loger à Paris. L'expérience des étudiants étrangers. Revue française de référence sur les dynamiques migratoires, 1308, 129-136. https://doi.org/10.4000/hommesmigrations.3013

Balibar, E. (2004). We the People of Europe: Reflections on Transnational Citizenship. Princeton University Press.

Bauman, Z. (1998). O mal-estar da pós-modernidade. Jorge Zahar.

BBC News (March 15, 2019).

https://www.bbc.com/portuguese/internacional-47586983?ocid=socialflow facebook

Beck, U. (2006). Cosmopolitan Vision. Polity.

Benhabib, S. (2012, July 29). The Morality of Migration. The New York Times. 
https://opinionator.blogs.nytimes.com/2012/07/29/stone-immigration

Bhabha, H. (1998). O local da cultura. UFMG.

Bieber, F. (2020). Debating Nationalism: The Global Spread of Nations. Bloomsbury. https://doi.org/10.5040/9781350098558

Bourdieu, P. (1990). The Logic of Practice. Stanford University Press. https://doi.org/10.1515/9781503621749

Burgin, V. (1996). In/Different Spaces: Place and Memory in Visual Culture. University of California Press.

Certeau, M. (1998). A invenção do cotidiano: 1. Arte de fazer. Vozes.

Douglas, M. (1991). Pureza e perigo. Edições 70.

Durkheim, E. (1999). A Divisão do Trabalho Social. Editora Martins Fontes.

Ethington, P. J. (2005). Georg Simmel y la cuestión de la espacialidad. Trayectorias, 7, 46-58.

Fanon, F. (1968). The Wretched Earth. Grove Press.

Frisby, D. (1992). Simmel and Since: Essays on Georg Simmel's Social Theory. Routledge.

Fuller, M. G., \& Löw, M. (2017). Introduction: An Invitation to Spatial Sociology. Current Sociology, 65, 469-491. https://doi.org/10.1177/0011392117697461

Georgiou, M. (2010). Identity, Space and the Media: Thinking through Diaspora. Revue Européenne des Migrations Internationales, 26, 17-35.

https://journals.openedition.org/remi/5028

https://doi.org/10.4000/remi.5028

Gibson, N. C. (2003). Fanon: The Postcolonial Imagination. Blackwell Publishing.

Gilroy, P. (2001). O Atlântico Negro. Modernidade e dupla consciência. 34/Universidade Cândido Mendes-Centro de Estudos Afro-Asiáticos.

Gilroy, P. (2007). Entre campos: Nações, cultura e o fascínio da raça. Annablume.

Harvey, D. (1992). Condição pós-moderna. Edições Loyola.

Jones, R. (2016). Violent Borders: Refugees and the Right to Move. Verso.

Kipfer, S. (2007). Fanon and Space: Colonization, Urbanization, and Liberation from the Colonial to the Global City. Environment and Planning D: Society and Space, 25, 701-726. https://doi.org/10.1068/dkipfer

Lefebvre, H. (2003 [1986]). Preface to the New Edition (from La Production de l'espace, 3rd edn, 1986). In S. Elden, E. Lebas, \& E. KOFMAN, Henri Lefebvre: Key Writings. New York e London: Continuum.

Leppänen, K. (2017). Crossing Borders and Redefining Oneself: The Treacherous Life of Aino Kallas. In M. Andrén, T. Lindkvist, I. Söhrman, \& K. Vajta (Eds.), Cultural Borders of Europe: Narratives, Concepts and Practices (pp. 128-142). Berghan Books.

Lorea, I. M. (2013). Prólogo. In H. Lefebvre (Ed.), La producción del espácio (pp. 9-31). Capitan Swing.

Löw, M. (2013). O Spatial Turn. para uma sociologia do espaço. Tempo Social, 25, 17-34. http://www.scielo.br/scielo.php?pid=S0103-20702013000200002\&script=sci abstract\&t $\underline{\operatorname{lng}=\mathrm{pt}}$ https://doi.org/10.1590/S0103-20702013000200002

Low, S. M. (2009). Towards an Anthropological Theory of Space and Place. Journal of the International Association for Semiotic Studies/Revue de l'Association Internationale de Sémiotique, 2009, 21-37. https://doi.org/10.1515/semi.2009.041

Massey, D. (2005). For Space. Sage. 
Mortimer, E. (2011). People, Nation and State: The Meaning of Ethnicity and Nationalism. I.B. Tauris. https://doi.org/10.5040/9780755620869

Nascimento, J. (2021). Pode o Subalterno Filmar? Cinema Africano e Luta Anticolonial nos Anos 1960. Bookerfield. https://doi.org/10.53268/BKF21090600

Nascimento, J. (2022). Promessas e Desafios da Migração: Reimaginando Espaços e Fronteiras a partir do Cinema Africano Contemporâneo. Atena. https://doi.org/10.22533/at.ed.257222101

Ponzanesi, S., \& Leurs, K. (2014). On Digital Crossings in Europe. Crossings: Journal of Migration \& Culture, 5, 3-22. https://doi.org/10.1386/cjmc.5.1.3 1

Robins, K. (2007). Transnational Cultural Policy and European Cosmopolitanism. Cultural Politics, 3, 147-174. https://doi.org/10.2752/174321907X194002

Said, E. (2003). Reflexóes sobre o exílio e outros ensaios. Companhia das Letras.

Sana, O., \& Oloo, A. (2019). Between the Borders and Internal Control: The Evolving Character of the Nation State in a Transnationalist Pastoralist Zone: A Case Study of the Turkana of Kenya and Karamojong of Uganda. Open Access Library Journal, 6, 1-22. https://doi.org/10.4236/oalib.1105506

Sassen, S. (2014). Expulsions: Brutality and Complexity in the Global Economy. Harvard University Press. https://doi.org/10.4159/9780674369818

Sayad, A. (1998). Imigração ou os paradoxos da alteridade. Edusp.

Sekyi-otu, A. (1996). Fanon's Dialectic of Experience. Harvard University Press.

Silverstone, R. (2004). Regulation, Media Literacy and Media Civics. Media, Culture and Society, 26, 440-449. https://doi.org/10.1177/0163443704042557

Simmel, G. (2013). Sociologia do espaço. Estudos Avançados, 27, 75-112. https://doi.org/10.1590/S0103-40142013000300007

Thomas, D. (2013). Africa and France: Postcolonial Cultures, Migration, and Racism. Indiana University Press.

Tönnies, F. (1979). Comunidad y asociación. El comunismo y el socialismo como formas de vida social. península.

Turner, J. (2018). Internal Colonisation: The Intimate Circulations of Empire, Race and Liberal Government. European Journal of International Relations, 24, 765-790.

https://doi.org/10.1177/1354066117734904

Turner, L. (1996). On the Difference between the Hegelian and Fanonian Dialectic of Lordship and Bondage. In L. Gordon, \& D. Sharpley-Whiting (Eds.), Fanon: A Critical Reader (pp. 134-154). Blackwell.

Urry, J. (2004). Connections. Environment and Planning D: Society and Space, 22, 27-37. https://doi.org/10.1068/d322t

Urry, J., \& Grieco, M. (2011). Mobilities: New Perspectives on Transport and Society. Ashgate Limited.

Werlen, B. (1993). Society, Action and Space: An Alternative Human Geography. Routledge.

Zambon, K. (2016). Negotiating New German Identities: Transcultural Comedy and the Construction of Pluralistic Unity. Media, Culture \& Society, 39, 552-567.

https://doi.org/10.1177/0163443716663640 